\title{
PENGEMBANGAN METODE ELISA DAN TEKNIK DETEKSI CEPAT DENGAN IMUNOSTIK TERHADAP ANTIBODI ANTI Aeromonas hydrophila PADA IKAN MAS (Cyprinid carpio)
}

\author{
Tatik Mufidah")\#, Heri Wibowo" ${ }^{\text {"*n }}$, dan Didik T. Subekti"*n") \\ ") Balai Penelitian dan Pengembangan Budidaya Air Tawar \\ ") Departemen Parasitologi, Fakultas Kedokteran, Universitas Indonesia \\ -m) Departemen Parasitologi, Balai Penelitian Veteriner, Bogor \\ (Naskah diterima: 18 Agustus 2015; Revisi final: 6 November 2015; Disetujui publikasi: 9 November 2015)
}

\begin{abstract}
ABSTRAK
Penelitian ini bertujuan untuk mengembangkan metode ELISA untuk deteksi antibodi anti Aeromonas hydrophila dan membuat alat deteksi cepat terhadap antibodi anti $A$. hydrophila dengan menggunakan imunostik. Sebanyak enam ekor ikan mas digunakan sebagai hewan uji untuk memproduksi serum seronegatif(baseline) dan seropositif. Hewan uji tersebut divaksinasi dengan antigen $A$. hydrophila dan dikoleksi serumnya tiap minggu. Optimasi metode ELISA dilakukan hingga mendapatkan rasio serum seronegatif dan seropositif yang terbaik. Hasil optimasi metode ELISA kemudian digunakan untuk merakit imunostik dan kemudian mengaplikasikannya pada serum ikan mas. Hasil uji optimasi metode ELISA didapatkan hasil bahwa metode ELISA yang dikembangkan dapat mendeteksi antibodi anti $A$. hydrophila pada semua serum positif dan menyatakan negatif pada serum seronegatif. Hasil yang sama juga ditunjukkan oleh uji imunostik yang telah dirakit.
\end{abstract}

KATA KUNCI: Aeromonas hydrophila, ELISA, imunostik

ABSTRACT: Development of elisa method and rapid detection using imunostick to detect antibody against Aeromonas hydrophila in carp (Cyprinid carpio). By: Tatik Mufidah, Heri Wibowo, and Didik T. Subekti

This research aims to develop an ELISA method for the detection of antibodies anti Aeromonas hydrophila and to make a rapid detection tool against the antibody anti A. hydrophila using imunostik. There are six carp are used as animals model for producing seronegative serum (baseline) and seropositive serum. The animals model were vaccinated with the antigen A. hydrophila and the serum was collected every week. ELISA optimization performed to obtain the best rasio of baseline and seropositive serum. ELISA method optimization results are then used to assemble imunostik and then apply it in carp serum. Optimization of ELISA test results showed that the developed ELISA method can detect antibodies anti A. hydrophila on all serum positive and negative states at seronegative serum. Similar results were shown by imunostik test that has been assembled.

KEYWORDS: Aeromonas hydrophila, ELISA, imunostick

\section{PENDAHULUAN}

Aeromonas hydrophila merupakan bakteri yang banyak terdapat di perairan terutama air dengan kandungan bahan organik yang tinggi (Yin, 2009). Bakteri ini dikenal sebagai agen patogen pada hewan akuatik, mamalia, reptil, ungags, dan manusia. Pada manusia A. hydrophila menyebabkan infeksi gastro-

\# Korespondensi: Balai Penelitian dan Pengembangan Perikanan Budidaya Air Tawar. Jl. Raya Sempur No. 1, Bogor 16154, Indonesia. Tel.: + (0251) 8313200

E-mail: fida.annisa@gmail.com enteritis pada individu sehat dan septikemia pada individu dengan kelainan sistem imun, penularan dapat terjadi melalui kontaminasi makanan dan luka pada kulit (Janda \& Sharon, 2010). Pada hewan akuatik khususnya ikan budidaya, A. hydrophila menyebabkan penyakit Motile Aeromonas Septicemia (MAS) yang mengakibatkan pertumbuhan ikan terganggu bahkan menyebabkan kematian. Ikan mas/karper merupakan salah satu ikan budidaya yang dilaporkan terserang $A$. hydrophila. Penyakit yang disebabkan oleh $A$. hydrophila pada ikan mas seringkali disebut ulcerative disease atau penyakit borok/penyakit merah. Serangan 
A. hydrophila pada ikan mas mulai dilaporkan pada tahun 1980 di Jawa Barat menyebabkan kematian kurang lebih 173 ton, dan 30\% di antaranya merupakan ikan-ikan kecil/benih (Lukistyowati \& Kurniasih, 2011). Infeksi $A$. hydrophila pada ikan mas bersifat akut hingga kronis dengan bentuk septikemia (Ismail et al., 2010). Gejala klinis pada infeksi akut yakni peradangan sistemik dan mengakibatkan kematian dalam waktu 24 sampai $48 \mathrm{jam}$. Tipe infeksi kronis ditandai dengan kerusakan pada bagian sirip, lesi pada kulit, gerakan renang lemah, dan menyebabkan kematian $10 \%$ sampai $70 \%$ dari total populasi ikan.

Salah satu usaha pencegahan dan penanggulangan infeksi $A$. hydrophila selama ini dilakukan dengan identifikasi bakteri menggunakan uji biokimia yang relatif membutuhkan waktu lama, dan akhir-akhir ini deteksi bakteri menggunakan metode molekuler telah dilakukan. Dalam rangka usaha pencegahan dan pengendalian A. hydrophila, selain mendeteksi bakteri penyebab infeksi, deteksi antibodi anti $A$. hydrophila perlu dikembangkan mengingat deteksi antibodi dapat digunakan sebagai uji skrining, diagnosa banding, dan konfirmasi infeksi $A$. hydrophila dan sekaligus dapat dimanfaatkan untuk mengukur efektivitas tindakan vaksinasi yang kini digalakkan. Berdasarkan latar belakang di atas, maka perlu dikembangkan metode deteksi dan sekaligus merancang alat deteksi cepat antibodi anti $A$. hydrophila pada ikan mas yang sensitif sekaligus diketahui hasilnya dengan cepat.

ELISA merupakan salah satu metode yang selama ini banyak digunakan untuk deteksi antibodi berdasarkan prinsip ikatan antigen-antibodi spesifik. Aplikasi metode ini digunakan untuk skrining maupun konfirmasi diagnosa suatu penyakit, akan tetapi pada kondisi tertentu uji ELISA terkadang tidak bisa dilakukan, hal tersebut dapat terjadi misalnya pada keperluan deteksi segera di lokasi kejadian penyakit, keterbatasan peralatan laboratorium, ketidaktersediaan bahan kimia, maupun tidak adanya tenaga laboratorium yang memiliki keahlian menjalankan tes dan perlunya hasil tes untuk segera diketahui (Subekti \& Kusumastuti, 2011). Untuk itu, selain pengembangan metode ELISA untuk deteksi antibodi anti $A$. hydrophila perlu juga dirancang alat diagnostik yang bisa digunakan untuk kondisi tersebut. Pengembangan tes diagnostik berdasarkan modifikasi prinsip ELISA dilakukan agar memungkinkan uji serologis dengan aplikasi yang mudah, cepat, tidak memerlukan fasilitas laboratorium yang lengkap, dan masih memungkinkan untuk dikembangkan menjadi uji serologi cepat, dan bersifat multi diseases-multi species. Salah satu uji yang layak dikembangkan untuk memenuhi keperluan di atas adalah dengan menggunakan imunostik. Uji ini biasa disebut uji cepat imunostik atau FELISA (field ELISA) yang mempunyai prinsip uji yang sama dengan ELISA yang dimodifikasi (Subekti dan Kusumastuti, 2011).

Pada akhirnya metode ELISA dan imunostik akan saling melengkapi untuk mendeteksi antibodi anti $A$. hydrophila pada ikan mas. Beberapa aplikasi dan penelitian mengenai uji cepat imunostik yang ada saat ini adalah imunostik untuk diagnosis cepat schistosomiasis (Rossi et al., 1991), Leptospirosis pada susu (Linnode bulletin, Ireland), toksoplasmosis (Jin, et al., 2005; Subekti \& Kusumastuti, 2011) diagnosis pada kasus rheumatoid arthritis (Asensio \& Samaniego, 2008); serta imunostik dalam keamanan pangan yaitu mendeteksi daging ikan kerapu (grouper) yang sering dipalsukan karena bernilai ekonomis tinggi di pasaran (Hyuk et al., 2011). Berdasarkan alasan-alasan tersebut di atas, maka penelitian ini bertujuan untuk mengembangkan metode ELISA dan membuat alat deteksi cepat imunostik untuk mendeteksi antibodi anti $A$. hydrophila pada ikan mas.

\section{BAHAN DAN METODE}

\section{Preparasi Antigen A. hydrophila}

Bakteri A. hydrophila yang digunakan sebagai antigen untuk vaksinasi ikan mas adalah bakteri yang telah diinaktivasi dengan menambahkan $0,3 \%$ formaldehid ke dalam biakan broth bakterin dan diinkubasi semalaman dengan distirer. Biakan bakteri kemudian dicuci lima kali dengan saline melalui sentrifugasi pada kecepatan $10.000 \mathrm{rpm}$ selama 30 menit. Penentuan konsentrasi bakteri sebanyak $10^{9} \mathrm{cfu} / \mathrm{mL}$ dilakukan dengan spektrofotometer diukur pada ë $620 \mathrm{~nm}$ dengan transmisi $10 \%$. Keamanan produk diuji dengan menanam kembali pada media agar TSA kemudian diinkubasi pada suhu $25^{\circ} \mathrm{C}$ selama 24 jam. Produk aman digunakan untuk vaksinasi ikan mas jika tidak tumbuh kembali jenis $A$. hydrophila yang sama seperti bakterin sediaan vaksin.

\section{Ikan Mas}

Ikan uji yang digunakan dalam penelitian ini adalah ikan mas berasal dari pembudidaya ikan di daerah Depok dengan umur 16 minggu bobot darat-rata 200 g. Ikan yang digunakan harus memenuhi asumsi Spesifik Pathogen Free (SPF) bebas dari karakteristik yang akan muncul ketika terinfeksi penyakit Motile Aeromonas Septicemia, melewati masa aklimatisasi selama empat hari.

\section{Sampel Serum}

Serum seronegatif (baseline) ikan mas diperoleh dari ikan mas sebelum divaksinasi dengan $A$. hydrophila. Serum seropositif ikan mas diperoleh dari 
ikan mas yang divaksinasi dengan antigen sel utuh $A$. hydrophila.

\section{Vaksinasi Pengambilan dan Penyimpanan Serum Ikan Mas}

Vaksinasi pada ikan mas dilakukan dengan menyuntikkan antigen yang telah diinaktivasi sebanyak $0,1 \mathrm{~mL}$ secara intra peritoneal. Vaksinasi dilakukan pada hari ke-1 dan diulang kembali (booster) pada hari ke-7. Pengambilan darah pada ikan mas dilakukan tiap minggu pada vena sirip ekor, darah yang telah dikoleksi kemudian disentrifus $3.000 \mathrm{rpm}$ selama lima menit. Serum diambil dan disimpan pada $-20^{\circ} \mathrm{C}$ untuk perlakuan lebih lanjut.

\section{Estimasi Konsentrasi Protein Sediaan Antigen A. hydrophila}

Konsentrasi protein sediaan antigen sel utuh $A$. hydrophila ditentukan menggunakan kurva standar BSA sesuai metode Bradford pada pelat mikroplate kemudian dibaca oleh ELISA Reader. Optical density (OD) dibaca menggunakan panjang gelombang $595 \mathrm{~nm}$.

Optimasi ELISA untuk Deteksi Antibodi Anti $A$. hydrophila pada Serum Ikan Mas

Optimasi metode ELISA dilakukan dengan melakukan variasi pengenceran antigen sel utuh $A$. hydrophila, pengenceran serum, antibodi kedua (secondary antibody), konjugat, dan waktu inkubasi substrat. Penggunaan seronegatif dan seropositif ikan mas dalam optimasi uji ELISA dilakukan karena pada saat optimasi kondisi ELISA belum diketahui apakah vaksin antigen sel utuh $A$. hydrophila dapat menginduksi respons antibodi spesifik $A$. hydrophila pada ikan mas. Optimasi ELISA dilakukan beberapa kali hingga didapatkan hasil uji ELISA yang memiliki rasio seronegatif dan seropositif terbaik.

Langkah kerja optimasi ELISA dilakukan sebagai berikut: larutan stok $A$. hydrophila dilapiskan sebagai antigen berkonsentrasi $0,5 \mu \mathrm{g} / \mathrm{mL} ; 2 \mu \mathrm{g} / \mathrm{mL} ; 5 \mu \mathrm{g} / \mathrm{mL}$; dan $10 \mu \mathrm{g} / \mathrm{mL}$ dalam coating buffer $(0,15 \mathrm{M}$ sodium karbonat; 0,35 M sodium bikarbonat; 0,03 M). Pelapisan pelat sumur ELISA dilakukan dengan memasukkan 100 $\mu \mathrm{L}$ antigen dalam coating buffer ke dalam pelat sumur ELISA pada suhu $4^{\circ} \mathrm{C}$ kemudian diinkubasi selama 24 jam. Kemudian pelat dicuci sebanyak tiga kali dengan $200 \mu$ L larutan pencuci PBST (PBS 1x; 0,05\% Tween-20). Antigen diblok dengan menambahkan $150 \mu \mathrm{L}$ blocking buffer (1\% Buffer Serum Albumin-Sigma, dalam PBS 1x) kemudian diinkubasi selama satu jam pada suhu $37^{\circ} \mathrm{C}$. Setelah dilakukan tiga kali pencucian dengan $200 \mu \mathrm{L}$ PBST, ke dalam sumur pelat ELISA dan selanjutnya dimasukkan $100 \mu \mathrm{L}$ serum ikan mas yang telah diencerkan dalam PBS + 0,1\% BSA.
Optimasi konsentrasi serum dilakukan dengan pengenceran serum 1:100 dan 1:400 dalam larutan 0,1\% BSA dalam PBS. Antibodi pertama (serum) diinkubasikan pada $37^{\circ} \mathrm{C}$ selama satu jam. Setelah dilakukan tiga kali pencucian dengan $200 \mu \mathrm{L}$ PBST, dimasukkan $100 \mu \mathrm{L}$ larutan antibodi kedua yaitu Mouse anti carp IgM dengan pengenceran 1:3.000. Inkubasi antibodi kedua dilakukan selama satu jam pada suhu $37^{\circ} \mathrm{C}$. Selanjutnya dimasukkan antibodi yang sudah diberi label dengan Horse Radish Peroksidase (HRP) dengan pengenceran 1:6.000, 1:12.000, 1:20.000 ke dalam sumur pelat dan diinkubasi pada suhu $37^{\circ} \mathrm{C}$ selama satu jam. Dalam penelitian ini, untuk optimasi ELISA baik antibodi pertama, kedua maupun antibodi ketiga dilarutkan dalam larutan 0,1\% BSA dalam PBS untuk meningkatkan spesivisitas ikatan antigenantibodi. Setelah dilakukan pencucian sebanyak tiga kali, kemudian ditambahkan $100 \mu \mathrm{L}$ substrat TMB Ultra (Pierce), pelat ELISA didiamkan selama 15-30 menit pada suhu ruang sampai terbentuk warna. Untuk menghentikan reaksi ke dalam sumur pelat ditambahkan $100 \mu \mathrm{L} 2 \mathrm{M} \mathrm{H}_{2} \mathrm{SO}_{4}$. Intensitas warna diukur dengan pembacaan optical density (OD) pada panjang gelombang $450 \mathrm{~nm}$ menggunakan ELISA microplate reader (UV Vis MultiScan G0 Thermo).

\section{Penyiapan Imunostik untuk Deteksi Antibodi}

\section{Anti $A$. hydrophila pada Serum Ikan Mas}

Perakitan imunostik dilakukan berdasarkan hasil optimasi ELISA yang menghasilkan rasio terbaik, sehingga antigen yang dilapiskan adalah $2 \mu \mathrm{L} / \mathrm{mL}$ dalam $10 \mathrm{~mL}$ buffer karbonat. Sebanyak $5 \mu \mathrm{L}$ antigen dan 5 $\mu \mathrm{L}$ serum dengan konsentrasi 7,5 $\mu \mathrm{L} / \mathrm{mL}$ dalam buffer karbonat dilapiskan pada permukaan imunostik. Pelapisan serum ikan mas dilakukan untuk kontrol imunostik. Imunostik kemudian diinkubasi pada $4^{\circ} \mathrm{C}$ selama 24 jam. Setelah tahap pelapisan antigen, tahap selanjutnya adalah blocking imunostik dengan direndam dalam larutan PBST 0,05 \%. Blocking dilakukan pada suhu $4^{\circ} \mathrm{C}$ selama 24 jam. Imunostik selanjutnya dicuci kembali dengan air kran mengalir, selanjutnya disimpan pada suhu $4^{\circ} \mathrm{C}$ dan siap digunakan.

\section{Deteksi IgM Anti A. hydrophila pada Serum Ikan Mas dengan Uji Imunostik}

Deteksi sampel serum ikan mas terhadap antibodi anti $A$. hydrophila dengan imunostik dilakukan dengan mengencerkan serum $(1: 100)$ dalam PBST 0,05\% pH 7,2 . Selanjutnya $800 \mu \mathrm{L}$ sampel serum yang telah diencerkan tersebut dimasukkan ke dalam tabung imunostik. Imunostik yang telah siap pakai direndam ke dalam tabung dan diinkubasi pada suhu ruang selama 10 menit. Setelah itu, imunostik dikeluarkan dari dalam tabung dan dicuci dengan air kran mengalir. Imunostik selanjutnya dimasukkan dan direndam di 
dalam tabung yang telah berisi mouse anti-carp monoclonal antibodi IgM (1:3.000) (Aquatic Diagnostic Ltd., Stirling, Scotland) diinkubasi di suhu ruang selama 10 menit. Setelah perendaman, imunostik kembali dicuci dengan air keran mengalir. Tahap selanjutnya adalah perendaman imunostik dengan $800 \mu$ L konjugat $R a b$ bit anti Mouse $\operatorname{IgG}$ yang berlabel HRP yang telah diencerkan dengan PBS + BSA 0,1\%. Reaksi ini dilakukan selama 10 menit pada suhu ruang. Kemudian stik kembali dicuci dengan air keran mengalir. Terakhir, imunostik dimasukkan dalam tabung yang telah berisi $800 \mu$ L larutan substrat O-Dianisidine/ODN Sigma, USA (0,015 ODN; 2,5mL DMSO; 25 mL PBS 1x; 22,5 mL Aquades; $20 \mu \mathrm{L} \mathrm{H}_{2} \mathrm{O}_{2}$ ) selama tiga menit. Imunostik kemudian dicuci dengan air keran mengalir dan dilihat secara visual. Apabila terdapat perubahan warna oranye bulat di permukaan imunostik pada lokasi pelapisan antigen $A$. hydrophila, maka sampel tersebut dinyatakan seropositif $A$. hydrophila. Apabila tidak terbentuk bulatan warna oranye maka dinyatakan seronegatif $A$. hydrophila (Subekti \& Kusumaningtyas, 2011).

\section{Analisis Statistik}

Analisis statistik yang digunakan untuk menganalisis data pada penelitian ini menggunakan SPSS dan dilanjutkan dengan analisis deskriptif pada uji dengan imunostik.

\section{HASIL DAN BAHASAN}

Estimasi Konsentrasi Protein Sediaan Antigen Sel Utuh A. hydrophila

Hasil estimasi pengukuran konsentrasi protein dengan Bradford menjadi dasar bagi antigen yang akan dilapiskan pada pelat ELISA. Dari hasil pengukuran protein yang dilakukan, didapat protein antigen $A$. hydrophila dengan konsentrasi $0,88 \mathrm{mg} / \mathrm{mL}$. Pada optimasi ELISA antigen yang dilapiskan berkonsentrasi 0,5 mg/mL, $2 \mathrm{mg} / \mathrm{mL}, 5 \mathrm{mg} / \mathrm{mL}, 10 \mathrm{mg} / \mathrm{mL}$.

\section{Optimasi ELISA}

Data optimasi uji ELISA, nilai rasio paling tinggi didapatkan pada komposisi ELISA dengan pengenceran antigen $2 \mu \mathrm{g} / \mathrm{mL}$ dan serum ikan mas 1:400, pengenceran IgM anti carpio 1:6.000, pengenceran antibodi kedua (Rabbit anti mouse HRP) 1:12.000, dan waktu untuk menghentikan reaksi antara substrat dan enzim menjadi 5 menit.

Hasil pembacaan ELISA reader terlihat nilai OD serum seronegatif ikan mas lebih rendah jika dibandingkan dengan serum setelah vaksinasi terutama pada minggu ketiga (Gambar 1). Penentuan serum positif dan negatif dari nilai OD hasil ELISA serum ikan mas ditentukan dengan menghitung nilai ambang (cut off). Nilai cut off dihitung dengan rumus sebagai berikut: Cut off = rata-rata OD serum negatif $+(2 \times \mathrm{SD})$.

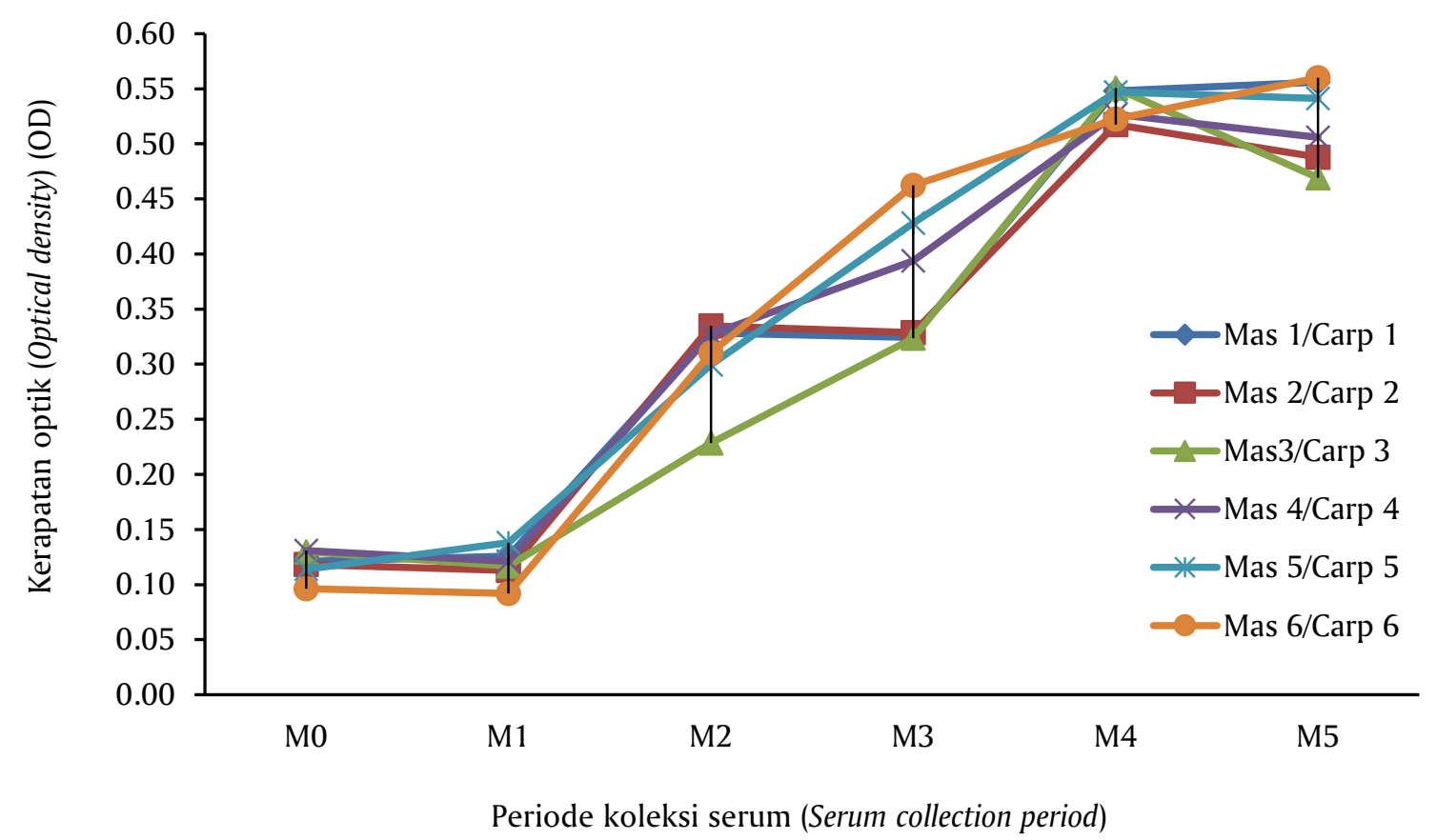

Gambar 1. Respons antibodi anti $A$. hydrophila tiap minggu, nilai cut off ELISA $=0,144$

Figure 1. Antibody responses of A. hydrophila in weeks, ELISA cut off $=0.144$ 


\section{Cut off}

Hasil perhitungan nilai cut off berdasarkan rumus di atas, didapatkan nilai cut off sebesar 0,144; berdasarkan nilai cut off maka nilai OD dari sampel serum ikan mas yang berada di atas garis cut off dinyatakan positif dan nilai OD serum ikan mas yang berada di bawah garis cut off dinyatakan negatif. Dari Gambar 1 diketahui bahwa nilai OD semua serum ikan mas pada minggu 2, 3, 4, dan 5 berada di atas garis cut off sehingga dinyatakan positif. Dan serum ikan mas pada minggu ke-0 (seronegatif) dan minggu ke-1 berada di bawah garis cut off dan dinyatakan negatif.

Analisis statistik dengan SPSS nilai OD serum ikan mas minggu ke-0 (seronegatif) dan minggu ke-1 tidak menunjukkan perbedaan yang signifikan $(>0,05)$; sedangkan serum ikan mas pada minggu ke-2, 3, 4, dan minggu ke- 5 berbeda nyata dengan serum minggu ke-0 (Gambar 2).

Protein $A$. hydrophila dengan konsentrasi bertingkat yaitu $0,5 \mu \mathrm{g} ; 2 \mathrm{ig} ; 5 \mu \mathrm{g}$, dan $10 \mu \mathrm{g}$ dilapiskan pada dasar sumur pelat ELISA berperan sebagai antigen dan digunakan tiga macam antibodi yaitu serum ikan mas yang divaksinasi $A$. hydrophila sebagai antibodi pertama yang berfungsi untuk mengenali antigen yang telah dilapiskan di dasar sumur pelat ELISA. Antibodi kedua yaitu Mouse anti carp IgM yang akan mengenali antibodi ikan mas dan antibodi ketiga Rabbit anti mouse IgG HRP yang berfungsi untuk mengenali keberadaan ikatan antigen-antibodi
(Gambar 3). Jika di dalam serum ikan mas yang telah diimunisasi terdapat antibodi anti $A$. hydrophila, maka antibodi tersebut akan berikatan dengan antigen $A$. hydrophila di dasar sumur pelat ELISA, selanjutnya antibodi kedua merupakan antibodi yang secara spesifik akan mengenali antibodi dari ikan mas. Antibodi kedua akan mendeteksi ikatan antara antibodi $A$. hydrophila dan antigen $A$. hydrophila dan ikut berikatan dengan kompleks antigen-antibodi yang sudah terjadi pada sumur di pelat ELISA. Selanjutnya ditambahkan larutan antibodi ketiga yang akan mengenali kompleks antibodi kedua - antibodi pertama - antigen $A$. hydrophila dan menghasilkan interaksi biologis non-kovalen. Larutan TMB (Tetra methyl benazidine) ditambahkan selanjutnya ke dalam pelat ELISA agar bereaksi dengan HRP. TMB berfungsi sebagai substrat bagi HRP, reaksi hidrolisis substrat oleh enzim menghasilkan warna dengan intensitas tertentu tergantung pada banyaknya kompleks antigen-antibodi yang terbentuk. Reaksi hidrolisis yang terjadi dihentikan dengan penambahan stop solution berupa asam sulfat $2 \mathrm{M}$. Pada penelitian ini teknik ELISA yang dikembangkan adalah metode ELISA indirek. ELISA (Enzyme Linked Immunosorbent Assay) merupakan suatu teknik pendeteksian antigen atau antibodi dengan menggunakan enzim yang telah diberi label misalnya enzim HRP (horseradish peroxidase). Teknik ELISA memiliki kelebihan misalnya sensitif dan sederhana dibandingkan teknik RIA (Radioimmunoassay) yang memerlukan bahan radioaktif (Pilstrom \& Bengten, 1996).

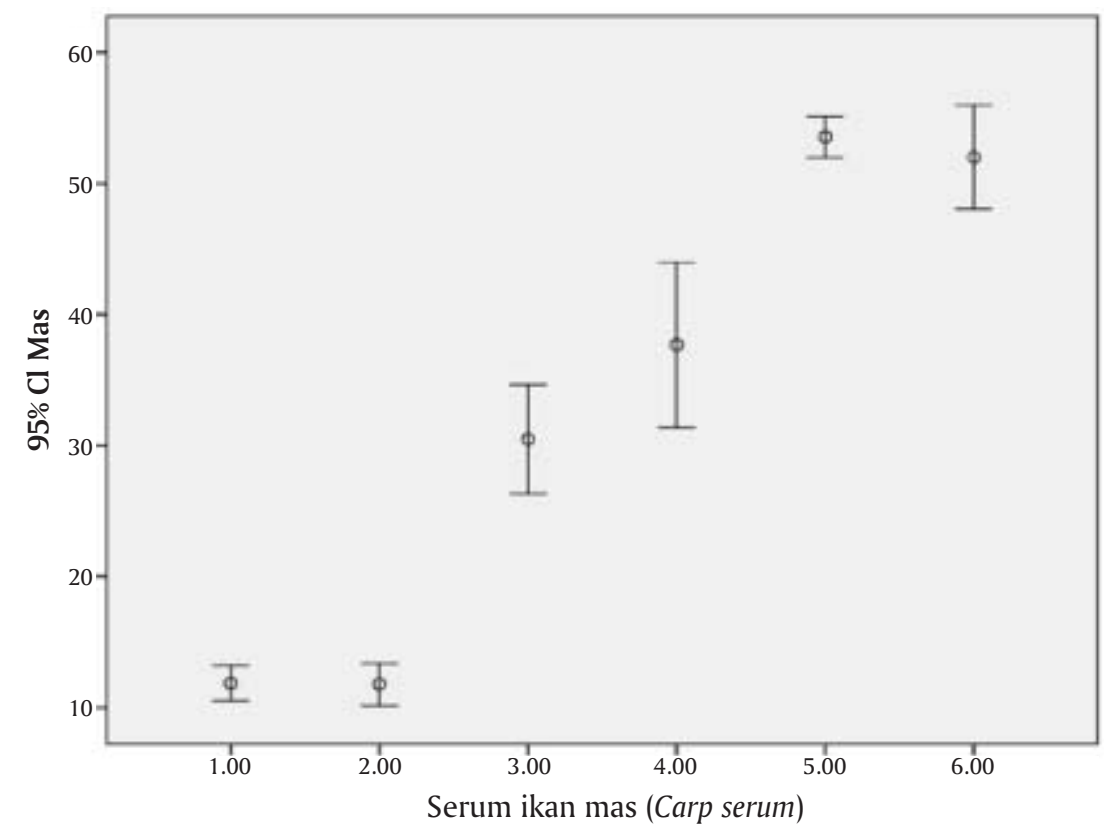

Gambar 2. Analisis perbedaan reaktivitas serum ikan mas berdasarkan periode koleksi serum

Figure 2. Analysis of differences carp serum reactivity in time periode 


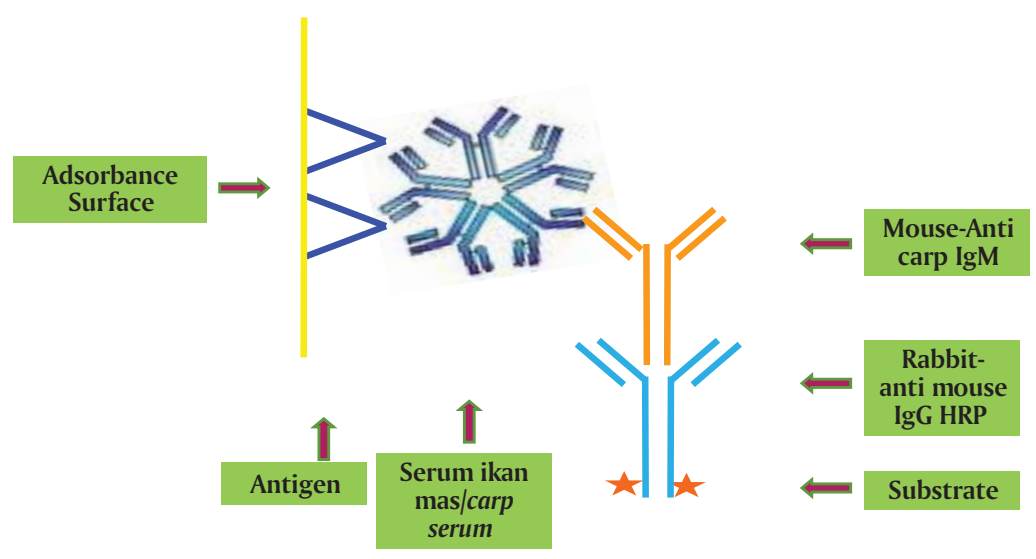

Gambar 3. Ilustrasi metode ELISA dan imunostik pendeteksi antibodi anti $A$. hydrophila

Figure 3. Illustrations of ELISA methode and immunostick to detect antibody anti A. hydrophila

\section{Uji Cepat Imunostik}

Deteksi A. hydrophila dengan imunostik dilakukan pada serum ikan mas dan serum kelinci. Hasil dinyatakan positif apabila terdapat perubahan warna pada lokasi antigen yang dilapiskan (Gambar 4A dan 4B). Dari hasil tersebut dapat diketahui bahwa imunostik dapat mendeteksi antibodi anti $A$. hydrophila melalui perubahan warna yaitu terdapat warna orange pada serum ikan mas. Dari hasil optimasi beberapa kali perakitan stik dan aplikasi serum, maka didapatkan hasil sebagai berikut (Tabel 1).
Dari hasil uji imunostik dapat diketahui bahwa imunostik dapat mendeteksi antibodi anti $A$. hydrophila pada serum ikan mas, jumlah serum yang berhasil dideteksi antibodi anti $A$. hydrophila sehingga dinyatakan sebagai serum positif berjumlah 22 serum, sedangkan serum yang negatif berjumlah 14 serum ikan mas. Jika dibandingkan dengan uji ELISA maka serum ikan mas yang dinyatakan positif oleh imunostik adalah serum dengan nilai $O D \geq 0,144$; hasil uji imunostik terhadap serum ikan mas terdapat pada Tabel 1.
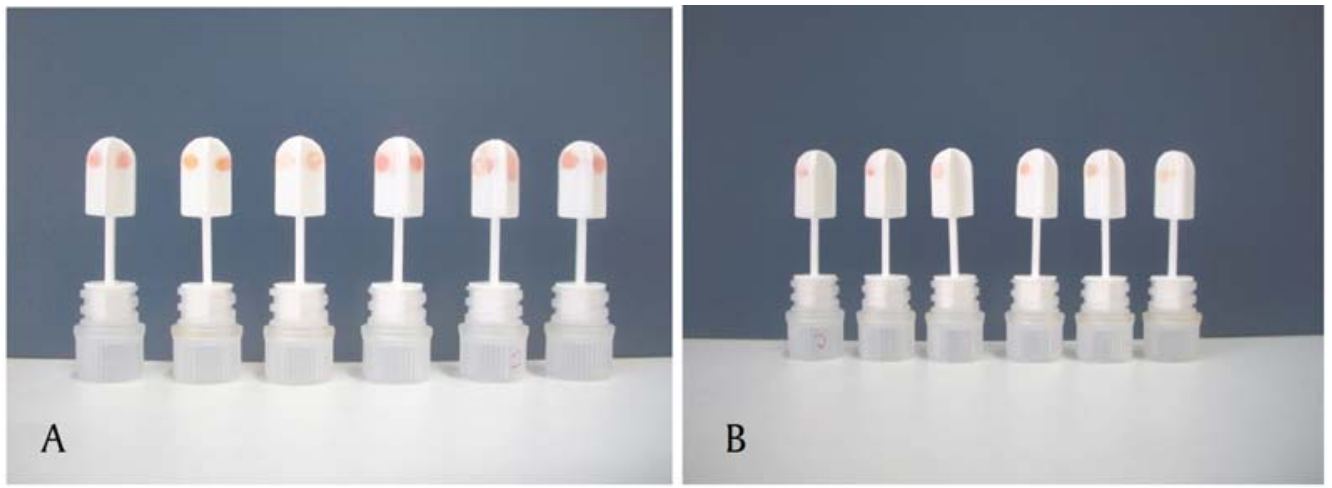

Gambar 4. Hasil uji imunostik pendeteksi antibodi anti $A$. hydrophila pada serum ikan mas, dua bulatan warna orange pada permukaan imunostik menunjukkan terdapat antibodi anti $A$. hydrophila dan kontrol imunostik yang menunjukkan imunostik berfungsi dengan baik (A); hasil uji imunostik dengan satu bulatan warna orange menunjukkan sampel serum negatif (B)

Figure 4. Imunostick test result to detect antibody anti A. hydrophila in carp serum, orange dot in show antibody anti A. hydrophila and imunostick control show that imunostick can work well (A); imunostick test result show that one orange dot indicated the serum is negative (B) 
Tabel 1. Uji imunostik pada serum ikan mas

Table 1. Imunostick test in carp serum

\begin{tabular}{ccccccc}
\hline \multirow{2}{*}{$\begin{array}{c}\text { Ikan mas } \\
\text { Crap }\end{array}$} & \multicolumn{6}{c}{ Minggu (Weeks) } \\
\cline { 2 - 6 } & $\mathbf{0}$ & $\mathbf{1}$ & $\mathbf{2}$ & $\mathbf{3}$ & $\mathbf{4}$ & $\mathbf{5}$ \\
\hline 1 & - & - & + & + & + & + \\
2 & - & - & + & + & + & + \\
3 & - & - & + & + & + & + \\
4 & - & - & - & + & + & + \\
5 & - & - & + & + & + & + \\
6 & - & - & - & + & + & + \\
\hline
\end{tabular}

\section{Perbandingan Uji ELISA dan Imunostik}

Perbandingan uji ELISA dan imunostik dalam mendeteksi antibodi anti $A$. hydrophila dilakukan beradasarkan nilai cut off untuk uji ELISA dan perubahan warna pada imunostik. Dari hasil perbandingan didapatkan hasil seperti tertera pada Tabel 2.

Dari Tabel 2 dapat dilihat bahwa berdasarkan nilai cut off uji ELISA dan tidak adanya perubahan warna pada imunostik sehingga dinyatakan negatif terhadap antibodi anti $A$. hydrophila terdapat pada seluruh serum ikan mas yang diambil pada minggu pertama $(100 \%)$ dan menyatakan positif $100 \%$ terdapat antibodi anti $A$. hydrophila baik pada uji ELISA maupun imunostik pada serum minggu ke-4. Serum ikan mas pada minggu ke-2 ketika diuji dengan ELISA menyatakan $100 \%$ positif mengandung antibodi anti A. hydrophila, akan tetapi imunostik menyatakan
$66,66 \%$ serum ikan mas yang positif mengandung antibodi anti $A$. hydrophila. Sedangkan minggu ke-3 uji ELISA menyatakan $100 \%$ serum ikan mas positif antibodi anti $A$. hydrophila, demikian pula imunostik menyatakan $100 \%$ serum ikan mas positif antibodi anti A. hydrophila. Dari hasil pengujian kedua metode ini menyatakan hal yang sama bahwa tidak terdapat antibodi anti $A$. hydrophila pada semua serum ikan mas pada semua serum minggu ke-0 dan minggu ke1, dan antibodi anti $A$. hydrophila terdeteksi pada semua serum ikan mas yang dikoleksi pada minggu ke-3.

Ellis (2001) mengatakan bahwa antibodi pada ikan paska vaksinasi dapat dideteksi setelah tiga minggu dan pembentukan respons imun pada ikan dapat dilakukan dengan imunisasi menggunakan vaksin yang memiliki kemampuan untuk menstimulasi sel imun,

Tabel 2. Perbandingan serum negatif dan serum positif pada uji ELISA dan imunostik

Table 2. Comparison negative and positive serum in ELISA and imunostick test

\begin{tabular}{|c|c|c|c|c|c|c|c|}
\hline & \multicolumn{7}{|c|}{$\begin{array}{l}\text { Serum ikan mas minggu ke- } \\
\text { Carp serum in week- }\end{array}$} \\
\hline & 0 & & 1 & 2 & 3 & 4 & 5 \\
\hline \multicolumn{8}{|l|}{ ELISA } \\
\hline $\begin{array}{l}\text { Persentase positif } \\
\text { Percentage positive }\end{array}$ & 0 & & 0 & 100 & 100 & 100 & 100 \\
\hline $\begin{array}{l}\text { Persentase negatif } \\
\text { Percentage negative }\end{array}$ & 100 & & 100 & 0 & 0 & 0 & 0 \\
\hline \multicolumn{8}{|c|}{ Imunostik (Immunostick) } \\
\hline $\begin{array}{l}\text { Persentase positif } \\
\text { Percentage positive }\end{array}$ & & 0 & 0 & 66.66 & 100 & 100 & 100 \\
\hline $\begin{array}{l}\text { Persentase negatif } \\
\text { Percentage negative }\end{array}$ & & 100 & 100 & 33.33 & 0 & 0 & 0 \\
\hline
\end{tabular}


sedangkan respons imun innate akan bekerja terlebih dahulu untuk mengeliminasi antigen yang masuk. Kedua respons imun ini memegang peranan penting dalam mekanisme kekebalan ikan terhadap serangan patogen (Busch, 1997). Kekebalan adaptif dapat terbentuk pada kelompok teleost dan dapat dideteksi dalam hitungan hari bahkan minggu (4-6 minggu) dengan dipengaruhi oleh suhu lingkungan. Pada imunisasi aktif, antigen yang masuk ke dalam tubuh akan dikenali oleh sel imun yang selanjutnya menginduksi respons imun spesifik. Proses boosting dilakukan untuk menstimulasi agar dihasilkan antibodi spesifik dengan titer tinggi. Pada dasarnya proses boosting merupakan paparan antigen yang sama sehingga sel-sel memori akan menghasilkan antibodi dalam jumlah yang lebih banyak. Proses boosting dilakukan ketika kadar antibodi hasil vaksinasi telah turun. Paparan antigen kedua diharapkan lebih efektif dalam menstimulasi respons imun dan tidak dinetralisasi oleh antibodi yang terbentuk dari vaksinasi pertama.

Aeromonas hydrophila merupakan tipe bakteri ekstraselular (Skinner et al., 2010; Anbarasu et al., 1998) yang mampu bereplikasi di luar sel host seperti pada sel darah, jaringan lunak, lumen, dan gastrointestinal. Salah satu mekanisme kejadian penyakit akibat bakteri patogenik adalah dengan mengeluarkan toksin, seperti endotoksin yaitu toksin yang berasal dari komponen bakteri seperti dinding sel bakteri. Endotoksin pada bakteri gram negatif disebut lipopolisakarida (LPS) yang merupakan aktivator poten untuk makrofag dan sel dendritik (Abbas et al., 2012). Endotoksin pada $A$. hydrophila salah satunya adalah lipopolisakarisa (LPS) (Krovacek et al., 1992; Mano et al., 2000). LPS merupakan salah satu penyusun dari outer membrane bakteri A. hydrophila (Merino et al., 1995). Mekanisme utama sistem imun innate pada bakteri ekstraseluler adalah aktivasi komplemen, fagositosis, dan respons inflamasi. Aktivasi komplemen diperantarai oleh LPS yang terdapat pada dinding sel bakteri gram negatif dengan mengaktifkan jalur alternatif, sedangkan bakteri yang mengekspresikan mannose akan mengaktifkan komplemen melalui jalur lektin. Hasil dari aktivasi komplemen adalah opsonisasi dan peningkatan fagositosis. Komplemen dengan produknya merangsang respons inflamasi dengan merekrut dan mengaktivasi leukosit. Fagosit menggunakan berbagai reseptor permukaan termasuk reseptor mannose dan reseptor scavenger untuk mengenali bakteri ekstraseluler dan menggunakan baik reseptor Fc dan komplemen untuk opsonisasi bakteri bersama antibodi dan protein komplemen. Sensor sitoplasmik produk mikroba dan Toll-like receptors (TLRs) akan merangsang aktivitas mikrobisidal untuk ikut dalam aktivasi fagositosis. Sel dendritik dan fagosit yang teraktivasi akan mengsekresi sitokin penginduksi infiltrasi leukosit ke lokasi infeksi untuk mendigesti dan menghancurkan bakteri (Abbas et al., 2012).

Sistem imun adaptif pada bakteri ekstraseluler berfungsi untuk memblokir infeksi, eliminasi mikroba, dan netralisasi toksin. Respons imun adaptif untuk bakteri ekstraseluler ditujukan untuk dinding sel antigen dan cell-associated toxins seperti polisakarida dan protein. Polisakarida merupakan antigen thymus-independent, dan kekebalan humoral adalah mekanisme utama pertahanan terhadap bakteri yang dienkapsulasi polisakarida. Mekanisme efektor yang digunakan oleh antibodi untuk memerangi infeksi di antaranya adalah netralisasi, opsonisasi, dan fagositosis, serta aktivasi komplemen melalui jalur klasik. Antibodi berafinitas tinggi yang dihasilkan akan berperan dalam proses netralisasi, opsonisasi, dan aktivasi komplemen. Protein pada bakteri ekstraseluler juga mengaktifkan sel $\mathrm{T} \mathrm{CD} 4^{+}$dengan memproduksi sitokin penginduksi inflamasi lokal, meningkatkan fagositosis dan aktivitas mikrobisidal makrofag dan neutrofil, serta merangsang produksi antibodi. Respons sel $\mathrm{T}_{\mathrm{H}} 17$ yang sebabkan oleh bakteri merekrut netrofil dan monosit sehingga mendorong inflamasi lokal pada lokasi infeksi bakteri. Bakteri juga menginduksi respons sel $\mathrm{T}_{\mathrm{H}} 1$, interferon- $\gamma\left(\right.$ IFN- $\gamma$ ) yang dihasilkan sel $\mathrm{T}_{\mathrm{H}} 1$ akan mengaktifkan makrofag untuk menghancurkan mikroba yang telah difagosit, merangsang aktivitas opsonisasi, dan aktivitas komplemen-antibodi (Abbas et al., 2012).

Reaksi antara antigen, serum ikan mas, antibodi kedua (mouse anti carp IgM), dan konjugat (rabbit anti mouse $\lg G H R P$ ) dan substrat TMB menghasilkan produk akhir berwarna kuning yang dibaca oleh mesin ELISA reader. Enzim horseradish peroksidase (HRP) digunakan secara luas dalam aplikasi biokimia terutama karena kemampuannya untuk memperkuat sinyal lemah dan meningkatkan pendeteksian molekul sasaran. Banyak substrat untuk enzim horseradish peroksidase digunakan dengan tujuan mengeksploitasi fitur yang diinginkan dari HRP. HRP mengkatalisis konversi substrat kromogenik (misalnya, TMB, DAB, ABTS) menjadi produk berwarna 3,3',5 5', tetramethylbenzidine (TMB) merupakan substrat yang lazim digunakan pada prosedur ELISA menggunakan enzim peroksidase. TMB tidak berwarna, dapat teroksidasi oleh $\mathrm{H}_{2} \mathrm{O}_{2}$ dan menghasilkan latar yang rendah. Peroksidase dapat mengkatalisa TMB menjadi produk dengan dua warna berbeda. Pada produk pertama akan berwarna biru pucat dan dibaca pada panjang gelombang $370 \mathrm{~nm}$ dan $652 \mathrm{~nm}$ (Gosling, 2005). Pada penambahan asam atau $\mathrm{H}_{2} \mathrm{O}_{2}$ pada produk yang berwarna biru tersebut akan 


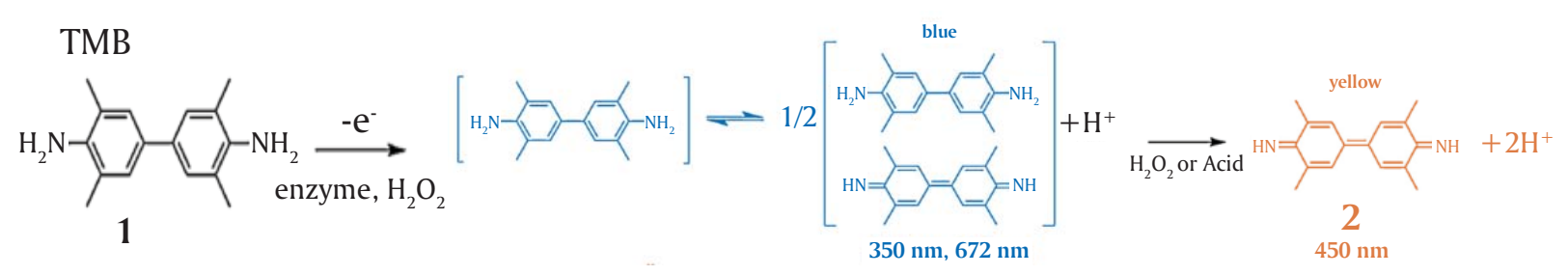

Gambar 5. Reaksi TMB dan peroksidase pada metode ELISA

Figure 5. Reaction of TMB and peroksidase in ELISA methode

berubah warna menjadi kuning yang stabil pada kondisi asam. Absorbsi maksimal dibaca pada panjang gelombang $450 \mathrm{~nm}$. Produk hasil katalisa TMB bersifat stabil dan dapat diamati secara langsung.

Berdasarkan hasil uji ELISA dan imunostik diketahui bahwa semua sampel serum ikan mas yang dinyatakan negatif oleh ELISA semuanya dinyatakan negatif juga oleh uji imunostik, akan tetapi tidak semua sampel serum positif yang dinyatakan oleh ELISA dinyatakan positif juga oleh uji imunostik. Beberapa sampel serum ikan mas yang dinyatakan sebagai sampel seronegatif $A$. hydrophila oleh imunostik meskipun terdeteksi seropositif oleh ELISA. Berdasarkan perlakuan pada hewan uji ikan mas yang diimunisasi dengan $A$. hydrophila, maka uji ELISA dapat mendeteksi sampel serum pasca imunisasi dengan lebih sensitif, karena dapat mendeteksi sampel serum berdasarkan nilai OD yang lebih besar.

Perbedaan hasil pembacaan imunostik dan ELISA pada serum ikan mas, hasil uji imunostik dapat mendeteksi positif pada semua serum ikan mas dengan OD di atas 0,31. Nilai OD 0,31 merupakan nilai OD terendah dari semua sampel serum ikan mas yang dinyatakan positif oleh imunostik (serum ikan mas nomor enam yang dikoleksi pada minggu ke-2). Hal tersebut berbeda dengan uji ELISA di mana dengan nilai cut off sebesar 0,144 maka semua serum dengan OD di atas 0,144 akan dinyatakan positif yaitu pada semua serum ikan mas yang dikoleksi pada minggu kedua dan minggu-minggu selanjutnya, sedangkan pada deteksi dengan imunostik terdapat serum ikan mas yang dikoleksi pada minggu kedua yang dinyatakan negatif (serum ikan mas no. 3 dan 5). Total serum ikan mas yang dinyatakan positif oleh uji ELISA adalah 24 serum, dan 12 serum ikan mas dinyatakan negatif. Sedangkan uji imunostik mendeteksi 22 serum ikan mas positif dengan nilai OD $>0,31$, dan 14 serum ikan mas dinyatakan negatif. Jika dilihat dari perlakuan pada ikan mas, di mana semua ikan mas diimunisasi dengan antigen $A$. hydrophila seharusnya kenaikan antibodi anti $A$. hydrophila pada ikan mas dapat terdeteksi positif pada minggu ketiga.
Pembacaan hasil uji ELISA yang berbeda dengan uji imunostik pada beberapa serum ikan mas kemungkinan karena adanya reaksi latar non-spesifik yang dibaca oleh mesin ELISA reader sedangkan imunostik hasil dibaca secara visual. Hal tersebut berpotensi mengakibatkan adanya perbedaan, karena ELISA akan mendeteksi serum sebagai seropositif sedangkan imunostik akan merevisi menjadi seronegatif melalui justifikasi secara visual. Latar nonspesifik juga sering dijumpai pada uji imunostik. Fenomena latar non-spesifik pada imunostik dapat terjadi karena beberapa hal, meskipun lebih sering dijumpai pada sampel seronegatif sesungguhnya (true negatif) tetapi proses pencucian selama tahap pengujian tidak dilakukan dengan baik sehingga masih terlihat kotoran yang menyebabkan reaksi non-spesifik (non specific background). Kualitas sampel serum yang diperoleh tidak terlalu baik juga berakibat reaksi nonspesifik meskipun pencucian selama tahap pengujian dilakukan dengan baik dan sempurna. Kondisi kedua dipertimbangkan sebagai sampel seronegatif apabila pengujian ulang menghasilkan hasil serupa dengan indikasi tidak ditemukan adanya bulatan oranye di antara warna latar tersebut.

Namun perbedaan hasil pembacaan uji ELISA dan uji imunostik tidak perlu dipersoalkan menurut Subekti \& Kusumaningtyas (2011) karena dapat ditetapkan solusinya. Apabila sampel terdeteksi seronegatif oleh imunostik dengan reaksi latar non-spesifik tetapi terdeteksi seropositif oleh ELISA maka sampel tersebut adalah seronegatif, karena adanya kemungkinan yang kuat terdapat reaksi positif palsu pada hasil uji ELISA. Sebaliknya apabila suatu sampel terdeteksi seronegatif tanpa reaksi latar non-spesifik (bersih), tetapi terdeteksi seropositif oleh ELISA, maka sampel cenderung dinyatakan seropositif karena hasil pembacaan spektrofotometer dipertimbangkan lebih peka dibandingkan dengan pengamatan visual oleh mata. Adapun di luar kedua kondisi tersebut maka harus dilakukan pengulangan uji dan evaluasi prosedur uji karena imunostik dan ELISA memiliki teknik dasar pengujian imunologi yang sama. 
Berdasarkan hasil penelitian, pada uji ELISA serum ikan mas mampu mendeteksi $100 \%$ serum ikan yang telah divaksinasi yaitu pada minggu ke-1, sedangkan uji imunostik baru menyatakan $66,66 \%$ serum ikan mas yang mengandung antibodi anti $A$. hydrophila. Uji imunostik baru menyatakan $100 \%$ sampel serum ikan mas mengandung antibodi anti $A$. hydrophila pada minggu ke-2. Pada minggu ke-3 uji ELISA telah dapat mendeteksi seropositif $100 \%$, dan imunostik mendeteksi seropositif $66,66 \%$. Persentase seropositif yang sama antara uji ELISA dan uji imunostik baru didapat pada minggu ke-4 dan selanjutnya minggu ke-5.

Substrat yang digunakan dalam uji imunostik adalah O-Dianisidine (3,3'-dimethoxybenzidine). ODianisidine adalah substrat peroksidase yang digunakan dalam prosedur uji serologis dengan menghasilkan produk akhir presipitat berwarna kuning-oranye (Gosling, 2005). Polistiren digunakan sebagai matriks solid-phase dari immunoassay. Polistiren yang merupakan bahan imunostik banyak dikembangkan untuk alat deteksi digunakan dalam situasi lapangan karena memiliki karakteristik yang memudahkan aplikasi karena konfigurasi fisiknya yang berupa stik dalam tabung polistiren. Sehingga reaksi positif dan negatif dapat dibedakan langsung secara visual. Pengembangan tes diagnostik oleh Al-Sherbiny et al. (1999) menyatakan perbedaan warna juga diperoleh ketika stik dicuci dengan air keran dan pencucian stik menggunakan air deionisasi ternyata warna yang muncul lebih terlihat nyata. Selain itu, stik yang sudah dilapisi antigen stabil bila disimpan pada $46^{\circ} \mathrm{C}$ untuk setidaknya tiga minggu. Dengan demikian, imunostik dapat dibuat dengan jumlah yang banyak kemudian disimpan, bahkan pada suhu kamar sampai diperlukan. Selain itu, tes membutuhkan volume serum yang sedikit, dan hemolisis yang terjadi tidak mengganggu tes imunostik. Pada akhirnya uji imunostik tidak memerlukan peralatan canggih dan cepat, setelah reagen siap, waktu uji lebih cepat.

\section{KESIMPULAN}

Berdasarkan hipotesis dan tujuan penelitian ini dapat disimpulkan bahwa teknik ELISA, di mana antigen yang ditempelkan pada pelat ELISA merupakan antigen sel utuh bakteri $A$. hydrophila yang diiaktivasi menggunakan formaldehid cukup efektif dan dapat untuk mendeteksi respons antibodi spesifik baik pada serum ikan mas yang diimunisai dengan antigen $A$. hydrophila.

Perakitan imunostik yang dilakukan dapat mendeteksi serum ikan mas yang positif terhadap antibodi anti $A$. hydrophila. Uji cepat imunostik dipertimbangkan sebagai pilihan deteksi antibodi anti
A. hydrophila karena memiliki akurasi yang baik dan dapat menjustifikasi sampel yang menunjukkan positif atau negatif palsu.

\section{UCAPAN TERIMA KASIH}

Penelitian ini dilakukan di Laboratorium Parasitologi Balai Besar Veteriner (Balitvet) Bogor dan Instalasi Penelitian dan Pengembangan Pengendalian Penyakit Ikan (IP4I), Depok. Penulis mengucapkan terima kasih kepada Kepala Laboratorium Parasitologi Balitvet, Ibu Dr. Angela Mariana Lusiastuti selaku Kepala Instalasi Penelitian dan Pengembangan Pengendalian Penyakit Ikan (IP4I), teman-teman Peneliti Lila Gardenia, Isti Koesharyani, dan Yani Aryati, tak lupa terima kasih sebanyak-banyaknya kepada rekan-rekan teknisi Sdr. Setiadi dan Johan Afandi.

\section{DAFTAR ACUAN}

Abbas, A.K., Lichtman, A.H., \& Pillai, S. (2012). Cellular and molecular immunology. Elsevier.

Al-Sherbiny, M.M., Osman, A.M., Hancock, K., Deelder, A.M., \& Tsang, V.C.W. (1999). Application of immunodiagnostic assays: detection of antibodies and circulating antigens in human schistosomiasis and correlation with clinical findings. Am. J. Trop. Med. Hyg., 60(6), 960-966.

Anbarasu, K., Thangakrishnan, K., Arun, B.V., \& Chandran, M.R. (1998). Assessment of immune responsse in freshwater Catfish (Mystus vittatus Bloch) to different bacterins of Aeromonas hydrophila. Indian Journal of Experimental Biology, 36, 990-995.

Asensio, L. \& Samaniego, L. (2008). Detection of grouper mislabelling in fish market by an immunostick colorimetric ELISA assay. Food and Agricultural Immunology, 19(2), 141-147.

Busch, R.A. (1997). Polyvalent vaccines in fish: the interactive effects of multiple antigens. In Gudding, R., Lillehaug, P.J., Midtlyng, P.J., \& Brown, F. (Eds.). Fish Vaccinology. Developments in Biological Standardization, Karger, 90, 245-56.

Ellis, A.E. (2001). Innate host defense mechanisms of fish against viruses and bacteria. Developmental and Comparative Immunology, 25, 827-839.

Gosling, J.P. (2005). Immunoassays. Oxford University Press. p. 95-99.

Ismail, N.E.A., Atta I, N.S., \& Ahmed, A.E.A.M. (2010). Oral vaccination of nile tilapia (Orechromis niloticus) against motile Aeromonas septicaemia. Nature and Science, p. 1-6.

Janda, J.M., \& Sharon, L.A. (2010). Pathogenicity and infection: taxonomy Aeromonas the genus. Clin. Microbiol. Rev., 23(1), 35. DOI: 10.1128/CMR.0003909. 
Jin, S., Chang, Z.Y., Ming, X., Min, C.L., Wei, H., Sheng, L.Y., \& Hong, G.X. (2005). Fast dipstick dye immunoassay for detection of immunoglobulin $G$ ( $\lg G$ ) and IgM antibodies of human Toxoplasmosis. Clin. Diagn. Lab. Immunol., 12, 198-201.

Krovacek, K., Faris, A., Baloda, S.B., Peterz, M., Lindberg, T., \& Mansson, I. (1992). Prevalence and characterization or Aeromonas spp. isolated from foods in Uppsala, Sweden. Food Microbiol., 9, 2936.

Lukistyowati, I., \& Kurniasih. (2011). Kelangsungan hidup ikan mas (Cyprinus carpio L.) yang diberi pakan ekstrak bawang putih (Allium sativum) dan di infeksi Aeromonas hydrophila. Jurnal Perikanan dan Kelautan, 16(1), 144-160.

Mano, S.B., Ordoez, J.A., \& Garcia de Fernando, G.D. (2000). Growth/survival of natural flora and Aeromonas hydrophila on refrigerated uncooked pork and turkey packaged in modified atmospheres. Food Microbiol., 17, 657-669.

Merino, S., Rubires, X., Knochel, S., \& Tomas, J.M. (1995). Emerging pathogens: Aeromonas spp. Int. J. Food Microbiol. 28, 157-168

Pilstrom, L., \& Bengten, E. (1996). Immunoglobulin in fish: genes, expression and structure. Fish and Shellfish Immunology, 6, 243-62.
Rossi, C.L., Tsang, V.C.W., \& Pilcher, J.B. (1991). Rapid, low-technology field - and laboratory applicable enzyme linked immunosorbent assays for immunodiagnosis of Schistosoma mansoni. J. Clin. Microbiol., 29, 183-1841.

Suwarno. (2003). Prinsip dasar, optimalisasi, dan interpretasi hasil uji ELISA. Surabaya. Laboratorium Virology dan Immunologi, Fakultas Kesehatan Hewan, Universitas Airlangga.

Skinner, L.A., Schulte, P.M., Balfry, S.K., McKinley, R.S., \& LaPatra, S.E. (2010). The association between metabolic rate, immune parameters, and growth performance of rainbow trout, Oncorhynchus mykiss (Walbaum), following the injection of DNA vaccine alone and concurrently with a polyvalent, oil-adjuvanted vaccine. Fish \& Shellfish Immunology, 28, 387-393.

Yin, G., Ardo, l., Thompson, K.D., Adams, A., Jeney, Z., \& Jeney, G. (2009). Chinese herbs (Astragalus radix and Ganoderma lucidum) enhance immune response of carp, Cyprinus carpio, and protection against Aeromonas hydrophila. Fish \& Shellûsh Immunology, 26, 140-145. 
Lampiran 1. Nilai OD pada optimasi uji ELISA

Appendix 1. OD value of the ELISA test optimization

\begin{tabular}{ccccccc}
\hline \multirow{2}{*}{$\begin{array}{c}\text { Ikan mas } \\
\text { Carp }\end{array}$} & $\mathbf{0}$ & $\mathbf{1}$ & $\mathbf{2}$ & $\mathbf{3}$ & 4 & $\mathbf{5}$ \\
\cline { 2 - 7 } & 0.2669 & 0.24515 & 0.87915 & 0.62585 & 1.5588 & 1.36765 \\
1 & 0.22925 & 0.5455 & 0.9342 & 0.52775 & 1.4933 & 0.7266 \\
2 & 0.2328 & 0.2452 & 1.04275 & 0.2338 & 1.4009 & 1.64665 \\
3 & 0.24515 & 0.3521 & 0.6815 & 1.2243 & 1.52955 & 1.29635 \\
4 & 0.5455 & 0.2461 & 0.4827 & 1.26755 & 1.3278 & 1.09065 \\
5 & 0.2452 & 0.303 & 0.65155 & 1.45465 & 1.54225 & 1.31325 \\
6 & \multicolumn{7}{c}{0.13085} \\
\hline PBS & \multicolumn{7}{c}{}
\end{tabular}




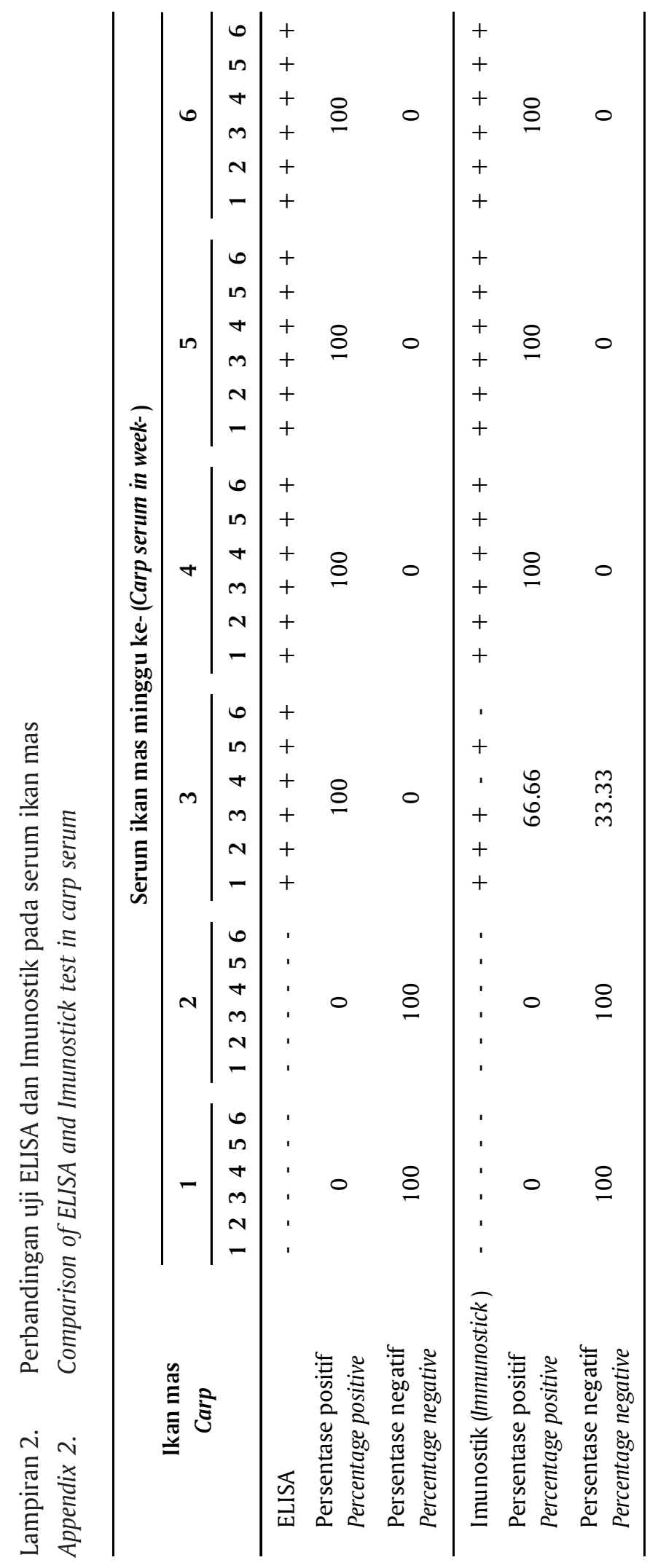


